\title{
Creating Strategies for Implementing Halal Logistics in Malaysia
}

\author{
Fitriatul Malaikhah ${ }^{1}$, Heti Mulyati ${ }^{2}$, Eko Ruddy Cahyadi ${ }^{3}$, Suhaimi Ab Rahman ${ }^{4}$ \\ \{fitriatul_malaikhah@apps.ipb.ac.id ${ }^{1}$, heti@apps.ipb.ac.id ${ }^{2}$, ekocahyadi@apps.ipb.ac.id ${ }^{3}$, \\ suhaimiabrahman@upm.edu.my $\left.{ }^{4}\right\}$ \\ Master Programme in Management, Sekolah Pascasarjana, IPB University, Babakan, Dramaga, \\ Bogor, West Java, 16680, Indonesia ${ }^{1}$ \\ Faculty of Economics and Management, IPB University, Babakan, Dramaga, Bogor, West Java, \\ 16680, Indonesia ${ }^{2,3}$ \\ School of Business and Economics, UPM, UPM Serdang, Malaysia ${ }^{4}$
}

\begin{abstract}
This study aims to build strategies for implementing halal logistics services in Malaysia. Data in this research were primary and secondary data. Primary data collected with observation method, in-depth interview with the expert, whose directly concern about halal and logistics. The respondents in this research are staff from JAKIM, HDC, and lecture from Halal Research Center UPM. Data in this research analyzed using SWOT analysis. The data that has been obtained then processed using SWOT analysis. From the results of the SWOT analysis, several strategies are obtained including: increase promotion and education about halal logistics, use IT or digital innovation, improve logistics infrastructure development, and hold training to increase capacity and understanding of halal logistics.
\end{abstract}

Keywords: Halal Logistics, Halal Supply Chain, Logistics Strategies, SWOT analysis

\section{Introduction}

Halal industries around the world have increased in recent years. Now, the halal marketplace is not only for Muslims, as non-Muslims are also turn to be interested in consuming halal results. Non-Muslims are absorbed in halal results as they conceive that halal results testament be also secured in terms of hygiene, cleanliness and the quality of the bread exhausted [1]. The increase in consumer awareness makes the halal market have great opportunities and 
potential to be obtained [2]. [3] predicted halal market will increase until 2027 (Figure 1):

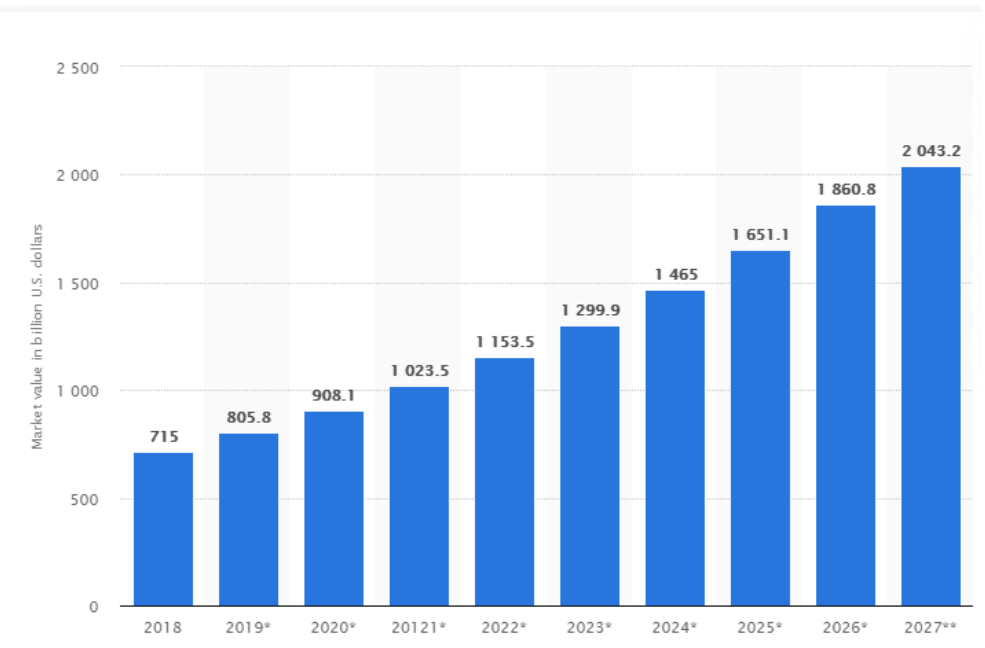

Figure 1 Growth of the global halal food market

The increasing requirement for halal products is also a challenge for the halal mnaufacture. The success of the halal marketplace is also influenced via the halal guarantee of a product [3]. Halal product ensures need to be maintained alongside the value chain such as transportation, storage and product handling. Hence, halal logistics performs a key role in defending halal integrity along the supply chain.

Halal logistics is very necessary to make sure the integrity of the halal supply chain from farm to end customers [4]. Halal logistics is a new phenomenon push by means of the wish of the halal manufacture to enhance the integrity of halal results [5]. Issues regarding halal logistics are increasing because level attention customers are increasingly. [6] prove that the application of halal logistics in port operations will provide substantial advantages for food companies getting into the halal market.

[8] in his study evidence the amount of the halal logistics market is US \$ 2.3 trillion with the largest distribution in Southeast Asia, the Middle East and Africa. This value is around IDR 30,000 trillion or 3 times the GDP of Indonesia. Muslim population growth around $1.86 \%$ per year, halal logistics market value is very lucrative. High market value and access makes Malaysia 
very prepared to become center in Southeast Asia for the logistics of halal products.

One of the countries with a Muslim majority population that has become a benchmark for halal logistics is Malaysia, besides that halal certification from Malaysia has also become an international standard [7]. According [8], in Malaysia, the authority to issue halal certificates is handled by the Department of Islamic Development Malaysia (JAKIM). Although, Malaysia's halal accreditation is recognized worldwide, interestingly halal logistics in Malaysia is nevertheless voluntary, it means that Malaysia does not require logistics companies to have halal certificates from JAKIM. Halal logistics is also one of the challenges that should be a threat to the improvement of the halal industry in Malaysia [9].

[10] mentioned that emerging trends for halal products and/or services have compelled logistics players to seek appropriate strategies to shift to halal business practices. In practical terms, it is not that simple because clients are demanding every aspect of the business to be halal, not only just the product but the business management as well. Since Malaysia also competing to achieve the global halal market, therefore this study required to construct strategies for implementing halal logistics in Malaysia.

\section{Literature Review}

\subsection{Logistics and Halal Logistics}

[11] defined logistics is the planning, organization, and control of all activities in the material flow, from raw material until final consumption and reverse flows of the manufactured product, with the aim of satisfying the customer's. In most cases logistics is seen from the perspective of an operative way of transporting or moving materials from one point to another or producing service.

According to [5], halal logistics is defined as the process of managing the procurement, movement, storage and handling of material parts, livestock, semi-finished or finished inventory both food and non-food, and related information and documentation flows through the organization and the supply chain in compliance with the general principles of Shariah (Islamic Law]. [12] described Halal logistics as similar to conventional logistics activities, comprising of planning, implementing and controlling the distribution and storage of Halal certified products from the source to the point of consumption. 
In Malaysia, the minimum requirement to be kept during for Halal logistics mention during the first part of MS 2400: 2010. MS 2400:2010 consists of three parts, which explain the requirement for halal logistics, halal warehousing and halal retailing. [13] mentioned that the most of the existing rules to ensure Halal integrity are related to the qualifications of people who work in the Halal food industry or the equipment they use, which basically doesn't influence the network. The following statements are regarded as the representative rules of Halal logistics.

- Separation from the Haram: Facilities, equipment and products that belong to Halal should be totally separated from Haram.

- The chain effect of Haram: If any types of Halal products contact Haram products, they cannot be credited as Halal anymore and are converted into Haram.

- Labour costs: The personnel, who are in direct or indirect contact with the goods, should always check their health status, have medical examinations, report illnesses, adhere to cleanliness standards and follow acceptable behaviour.

- Maintenance costs: All the equipment should be cleaned following Shariah ritual cleansing rules.

\subsection{Strategic Management}

Strategic management is described as an objective, logical, and systematic for making big decisions in the organization. Strategic management tries to organize qualitative and quantitative information so as to enable effective decision making in conditions of uncertainty surrounding them [14].

Strategy management has three stages according to [14] including :

1. Strategy formulation. Strategy formulation is the initial stage carried out in the strategy management process.

2. Implementation of the Strategy, at this stage the development of strategies supporting culture, effective organizational structure, rearranging the marketing efforts undertaken, preparing budgets, developing information systems, and linking workforce compensation to organizational performance.

3. Strategy Evaluation and Oversight, the stage of supervision of all organizational activities, whether it is already in line with the chosen strategic planning, uses a comparative analysis method of actual achievement conditions compared to the initial planning. 


\subsection{SWOT Analysis}

SWOT analysis is a tool used for strategic planning and strategic management in organizations. It can be used effectively to build organizational strategy and competitive strategy. In accordance with the system approach, organizations are wholes that are in interaction with their environments and consist of various sub-systems [15]. Underlying any successful selection of strategies is an analysis of the organization's internal strengths and weakness that are posed by internal environment and the opportunities and threats that are posed by the external environment [15].

\section{Research Methodology}

\subsection{Types and Sources of Data}

The data in this study are primary data and secondary data. Primary data collection is carried out by observation methods, in-depth interviews with experts who are directly related to halal and logistics. The primary data is used to obtain the information, assessment quality, objective and measurement to formulation strategies for implementing halal logistics. Secondary data are taken from institution's database, journal, annual reports, books, and another open sources databases.

In this study, the selection of experts used nonprobability methods and for data collection used purposive sampling technique. Respondent consist of experts that chosen according to expressly and constitute actors directly had a concern with halal logistics. The respondents are staff from JAKIM, staff from HDC, lecture from Halal Product Research UPM and staff from halal logistics company in Malaysia.

Data collection methods consist of two parts. The first part is a literature review and the second part is the interview with the respondent. Literature is obtained from more than a few databases such as Emerald, ScienceDirect, Research Gate with the keywords halal, halal logistics, SWOT. The literature used in this study is limited to only publications in English. To reduce the subjectivity of SWOT analysis was conducted an interview with the experts and local government officers; especially on weighting, scoring and material determination. To obtained the strategy, the data is processed using SWOT analysis.

\subsection{Data Processing and Analyzing Methods}




\subsubsection{SWOT Analysis}

The strength-weakness-opportunities-threats (SWOT) analysis is one of the most popular tools in use for defining an organization's strategy. This research presents the SWOT analysis methodology to discover and diagnose the core competencies and core problems of an organization. Table 1 shows the external and internal factors that influence in implementing halal logistics, namely transportation, warehousing, and handling to facilitate halal food. We have obtained these factors from the literature study.

Table 1 The external and internal factors

\begin{tabular}{ll}
\hline Category & Items \\
\hline Strengths & 1. Countries with good image as a modern [13], [16], [17] \\
Islamic country & 2. Halal product has a high demand among \\
& Muslim countries \\
3. Membership in business forum/associations & with other countries \\
4. Organization willingness to adopt halal \\
logistics and leadership \\
5. Halal logistics has a good performance to \\
collaborate and form a consortium \\
6. Complexity understand what the concept of \\
halal \\
7. Excellent trade facilitation \\
8. Pro-business, investment, and trade policy \\
1. Some companies only have a short-term [13], [16], [18], [19], [17]. \\
business perspective \\
2. Lack of information about the legal, social \\
and cultural surroundings in the importing \\
country. \\
3. There is no constant provider. \\
4. Lack of information and education on \\
product improvement. \\
5. Halal business do not have ample capital to \\
correctly export to different nations. \\
6. Some halal product companies do not comply \\
with market label requirements \\
8. The hatively long time
\end{tabular}


10. There is always a risk of pass infection between halal products and non-halal products

11. The absence of halal logo

12. Lack of ability and experience

13. The mind-set of some employees who omit halal practices

14. It is hard to make sure a hundred percent protected handling

15. There is no trendy packaging for halal products

Opportunities 1. The increasing population of Muslim around [13], [16], [17] the world

2. Some countries have as high purchasing power

3. Halal global trade potential

4. Strong logistics economy growth

5. Increased use of IT in Halal logistics

6. Changes in consumer preferences towards Halal

7. Muslim majority population

8. Strong government supports for developing halal logistics activities [reducing tax or duty]

9. Strong commitment by the government to increase halal product

10. Located along strategic shipping lines

11. The growth in worldwide Muslim consumers

12. Government agencies in the countries contribute to developing awareness among international consumers

16. The management aware with halal logistics

Threats $\begin{aligned} & \text { 1. Lack of international research and [13], [16], [17], [20], [21] } \\ & \text { development in halal logistics }\end{aligned}$
2. No uniformity in halal
3. The lack of collaborative effort between
logistics service providers and nearby or
foreign halal authorities
4. Absence of international halal certification
5. System compatibility alongside the Halal
logistics supply chain
6. Halal logistics is not mandatory
7. Lack of more campaigns, advertisements and
training for halal awareness
8. Differences of opinion and perspective
between logistics providers and halal
institutions regarding halal logistics practices
9. There is no relevant information from the
sender regarding halal products


Matrix approach of internal and external factors is weighted by factor 0.0 1.0 depending on how is the importance of factors. Furthermore, the strengths and opportunities as internal and external factors are given the score 1- 4 depending on how the effect of the factors to implementing halal logistics. To reduce the subjectivity of SWOT analysis was conducted deep discussion to experts and local government officers; especially on weighting, scoring and material determination.

\section{Empirical Results}

\subsection{Internal and External Factor Evaluation}

Internal environmental analysis is carried out through the identification of internal factors in halal logistics to determine their strengths and weaknesses. Once identified, weighting and rating are given for each variable. After weighting and rating value of each internal and external factor, then the score for each factor is obtained. Values range from 0.1 to 4.0, with an average of 2.5. A total average under 2.5 represents a weak internal organization, whilst above 2.5 indicates a strong internal position [22].

Based on the results of weighting and ranking using the IFE matrix, the total score of the IFE matrix is 2.54 , which means that the position of halal logistics in Malaysia is in a strong position.

Table 2 IFE Matrix Results

\begin{tabular}{lllc}
\hline The Strength & Weight & Rating & Score \\
\hline Countries with good image as a modern Islamic country & 0.042 & 3.52 & 0.147 \\
\hline $\begin{array}{l}\text { Halal product has a high demand among Muslim } \\
\text { countries }\end{array}$ & 0.041 & 2.52 & 0.104 \\
\hline $\begin{array}{l}\text { Membership in business forum/associations with other } \\
\text { countries }\end{array}$ & 0.047 & 2.76 & 0.129 \\
\hline $\begin{array}{l}\text { Halal logistics has a good performance to collaborate } \\
\text { and form a consortium }\end{array}$ & 0.046 & 2.52 & 0.116 \\
\hline $\begin{array}{l}\text { Excellent trade facilitation } \\
\text { n }\end{array}$ & 0.045 & 2.76 & 0.124 \\
\hline
\end{tabular}




\begin{tabular}{|c|c|c|c|}
\hline Pro-business, investment, and trade policy & 0.044 & 2.76 & 0.120 \\
\hline Having a halal certificate provides many benefits & 0.034 & 2.96 & 0.101 \\
\hline Traceability for halal products & 0.048 & 2.76 & 0.134 \\
\hline TOTAL & & & 1.084 \\
\hline The weakness & Weight & Rating & Score \\
\hline $\begin{array}{l}\text { Some companies only have a short-term business } \\
\text { perspective }\end{array}$ & 0.045 & 2.76 & 0.125 \\
\hline There is no constant provider & 0.038 & 2.04 & 0.077 \\
\hline $\begin{array}{l}\text { Lack of information and education on product } \\
\text { improvement }\end{array}$ & 0.045 & 2.76 & 0.124 \\
\hline $\begin{array}{l}\text { Halal business do not have ample capital to correctly } \\
\text { export to different nations }\end{array}$ & 0.045 & 1.80 & 0.082 \\
\hline $\begin{array}{l}\text { Some halal product companies do not comply with } \\
\text { market label requirements }\end{array}$ & 0.030 & 2.48 & 0.075 \\
\hline Ambiguous halal guidelines & 0.040 & 2.24 & 0.090 \\
\hline $\begin{array}{l}\text { The halal certification procedure takes a relatively long } \\
\text { time }\end{array}$ & 0.035 & 2.76 & 0.098 \\
\hline There are no special halal assets and facilities & 0.043 & 2.52 & 0.109 \\
\hline $\begin{array}{l}\text { There is always a risk of pass infection between halal } \\
\text { products and non-halal products }\end{array}$ & 0.053 & 2.76 & 0.145 \\
\hline The absence of halal logo & 0.042 & 2.00 & 0.085 \\
\hline Lack of ability and experience & 0.052 & 2.00 & 0.104 \\
\hline $\begin{array}{l}\text { The mind-set of some employees who omit halal } \\
\text { practices }\end{array}$ & 0.053 & 2.00 & 0.105 \\
\hline $\begin{array}{l}\text { Lack of information about the legal, social and cultural } \\
\text { surroundings in the importing country }\end{array}$ & 0.036 & 2.96 & 0.107 \\
\hline $\begin{array}{l}\text { It is hard to make sure a hundred percent protected } \\
\text { handling }\end{array}$ & 0.032 & 2.52 & 0.082 \\
\hline There is no trendy packaging for halal products & 0.020 & 2.76 & 0.055 \\
\hline TOTAL & & & 1.461 \\
\hline
\end{tabular}


EFE matrix analysis is the result of identifying external factors in the form of opportunities and threats that affect halal logistics. The result of multiplication between weighting averages and rating ratings will produce a total score. Based on the results of weighting and rating using the EFE matrix, the total score of the EFE matrix is 2,796. This value is at above an average of 2.50 that shows that Malaysia's strategies to implementing halal logistics has been effective in taking advantage of opportunities and minimizing threats or negative external effects.

Table 3 EFE Matrix Results

\begin{tabular}{|c|c|c|c|}
\hline The opportunities & Weight & Rating & Score \\
\hline The increasing population of Muslim around the world & 0.054 & 3.96 & 0.212 \\
\hline Some countries have as high purchasing power & 0.046 & 3.24 & 0.150 \\
\hline Halal global trade potential & 0.051 & 3.48 & 0.177 \\
\hline Strong logistics economy growth & 0.047 & 3.52 & 0.167 \\
\hline Increased use of IT in Halal logistics & 0.052 & 3.72 & 0.193 \\
\hline Changes in consumer preferences towards Halal & 0.045 & 2.76 & 0.124 \\
\hline Muslim majority population & 0.046 & 3.00 & 0.137 \\
\hline $\begin{array}{l}\text { Strong government supports for developing halal logistics } \\
\text { activities }\end{array}$ & 0.049 & 3.04 & 0.147 \\
\hline $\begin{array}{l}\text { Strong commitment by the government to increase halal } \\
\text { products }\end{array}$ & 0.050 & 3.52 & 0.175 \\
\hline Located along strategic shipping lines & 0.046 & 3.28 & 0.150 \\
\hline The growth in worldwide Muslim consumers & 0.047 & 3.24 & 0.153 \\
\hline $\begin{array}{l}\text { Government agencies in the countries contribute to } \\
\text { developing awareness among international consumers }\end{array}$ & 0.045 & 2.32 & 0.103 \\
\hline The management aware with halal logistics & 0.039 & 2.32 & 0.091 \\
\hline TOTAL & & & 1.981 \\
\hline The Threats & Weight & Rating & Score \\
\hline $\begin{array}{l}\text { Lack of international research and development in halal } \\
\text { logistics }\end{array}$ & 0.041 & 2.00 & 0.081 \\
\hline
\end{tabular}




\begin{tabular}{lccc}
\hline No uniformity in halal & 0.039 & 2.28 & 0.090 \\
\hline $\begin{array}{l}\text { The lack of collaborative effort between logistics service } \\
\text { providers and nearby or foreign halal authorities }\end{array}$ & 0.038 & 2.48 & 0.093 \\
\hline Absence of international halal certification & 0.045 & 2.28 & 0.102 \\
\hline $\begin{array}{l}\text { System compatibility alongside the halal logistics supply } \\
\text { chain }\end{array}$ & 0.045 & 2.04 & 0.091 \\
\hline $\begin{array}{l}\text { Halal logistics is not mandatory } \\
\text { Lack of more campaigns, advertisement, and training for } \\
\text { halal awareness }\end{array}$ & 0.040 & 2.52 & 0.101 \\
\hline $\begin{array}{l}\text { Differences of opinion and perspective between logistics } \\
\text { providers and halal institutions regarding halal logistics } \\
\text { practices }\end{array}$ & 0.046 & 1.80 & 0.085 \\
\hline $\begin{array}{l}\text { There is no relevant information from the sender } \\
\text { regarding halal products }\end{array}$ & 0.044 & 2.04 & 0.083 \\
\hline \begin{tabular}{l} 
TOTAL \\
\hline
\end{tabular} & & & 0.090 \\
\hline
\end{tabular}

\subsection{IE Matrix}

Based on the results of the IFE matrix and the EFE matrix, it can be arranged in the IE matrix. The average IFE score was 2.54 and the average EFE was 2.796. The average value of IFE and EFE is obtained from the sum of the scores for each factor, where the score is obtained from the multiplication of the average value with the average weight for each factor. This value shows the position of quadrant $\mathrm{V}$, which can be managed as well as possible with a guard and maintain strategy.IE matrix can be seen in Figure 2. 


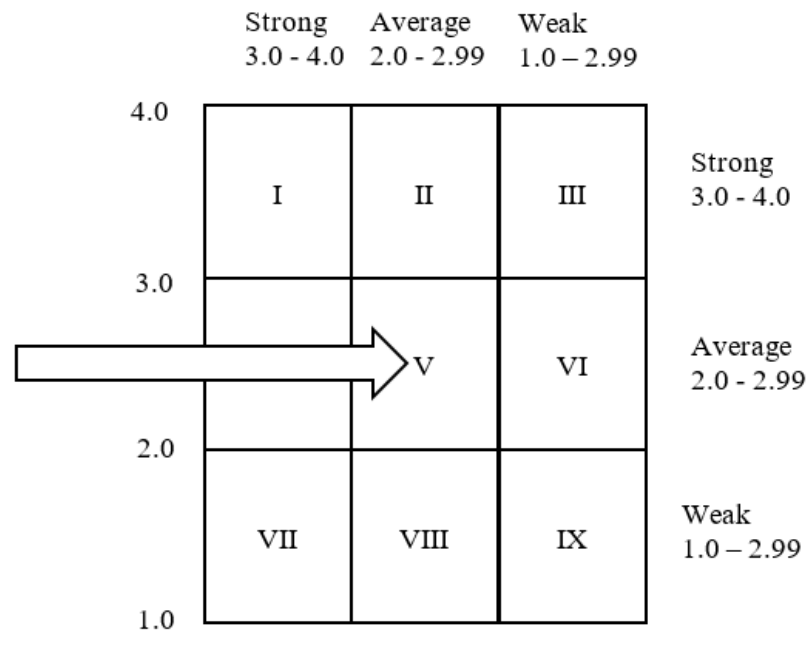

Figure 2 IE Matrix

\subsection{SWOT Matrix}

The SWOT matrix produces several alternative strategies obtained from internal and external variables according to the company's position in the IE matrix, Grow and build strategy. The alternative strategies can be seen in Table 4:

Table 4 SWOT Matrix

\begin{tabular}{|c|c|c|}
\hline & Strength & Weakness \\
\hline \multirow[t]{2}{*}{ Opportunities } & SO Strategies & WO Strategies \\
\hline & $\begin{array}{l}\text { 1. Promotion } \\
\text { 2. Research development to } \\
\text { improve halal guarantee } \\
\text { 3. Harmonization standard } \\
\text { halal with other countries }\end{array}$ & $\begin{array}{l}\text { 1. To advance surveillance and } \\
\text { certification systems using IT / } \\
\text { digital innovation }\end{array}$ \\
\hline \multirow[t]{2}{*}{ Threats } & ST Strategies & WT Strategies \\
\hline & $\begin{array}{l}\text { 1. Development of logistics } \\
\text { infrastructure }\end{array}$ & $\begin{array}{l}\text { 1. Training and capacity } \\
\text { building }\end{array}$ \\
\hline
\end{tabular}




\section{SO Strategies}

By using internal strength to keep away from or reduce the influence of external threats [14], it is encouraged that government organizations in the countries contributing to develop consciousness among worldwide consumers with promoting of halal products. What's more, government support through collaborates with academics to conduct research to enhance halal guarantee. In addition, logistics company can keep relation with different country by make harmonization standard.

\section{WO Strategies}

Moreover, to improve internal weaknesses and take beneefit of external opportunities [14], weak point such as the mid-set of some employees who ignoring in managing halal practices and tough to make certain one hundred percent safe handling is increasing the use of IT or digital innovation in halal logistics.

\section{ST Strategies}

By using internal strength to avoid or limit the impact of external threats [14], it is recommended to upgrade the logistics infrastructure. Advice strategies can be used to keep away from various threats, such as the absence of relevant information from the sender involving halal products.

\section{WT Strategies}

Finally, [14] stated that a protection method is needed to reduce internal weakness and avoid possible external threats. To gain this, it is recommended to conduct training and capacity building

\section{Conclusions}

The trend of the halal lifestyle does not only occur in countries where the majority of thepopulation is Muslim, but also in countries with Muslim minorities as seen from the large spending on world halal products as previously mentioned. So that opportunities for the development of halal products and industries are very open today and in the future in various regions of the world. The increasing demand for halal products encourages the importance of halal logistics.

Malaysia already has sufficient awareness about the importance of halal logistics. The results of the IE matrix calculation show that the strategy 
that can be applied in Malaysia for halal logistics is a grow and build strategy. The success of halal logistics in Malaysia can be achieved if there is good and consistent collaboration from all providers, namely the government, authority, logistics company, and consumers.

In this study several strategic suggestions that can be applied by several stakeholders are generated to implement halal logistics in Malaysia. The government and authorities can harmonize halal standards with other countries and increase promotion and education about halal logistics in other countries. Meanwhile, the logistics industry can apply to use IT or digital innovation, improve logistics infrastructure development, and hold training to increase capacity and understanding of halal logistics. Academics can increase research to increase the guarantee of halal products in the logistics process. Of course, these strategies can be achieved if there is good collaboration and commitment from these stakeholders.

\section{Acknowledgments}

Our thanks to the International Collaboration Office (ICO) IPB University, School of Business and Economics, UPM Malaysia, and Department of Management, IPB University for the support and collaboration in the Research Attachment Program.

\section{References}

[1] Mathew VN, Abdullah AMR binti A, Ismail SN binti M. Acceptance on Halal Food among Non-Muslim Consumers. Procedia - Soc Behav Sci [Internet]. 2014;121:262-71. Available from: http://dx.doi.org/10.1016/j.sbspro.2014.01.1127

[2] Hamid A, Said M, Meiria E. Potency and Prospect of Halal Market in Global Industry: An Empirical Analysis of Indonesia and United Kingdom. Bus Manag Stud. 2019;5(2):54.

[3] Syahbandeh. Halal Food Market Revenue Worldwide 2018-2027 [Internet]. 2019. Available from: https://www.statista.com/statistics/785499/halal-food-market-revenueglobal/

[4] Soon JM, Chandia M, Regenstein J Mac. Halal integrity in the food supply chain. Br Food J. 2017;119(1):39-51.

[5] Tieman M. The application of Halal in supply chain management: Indepth interviews. J Islam Mark. 2011;2(2):186-95.

[6] Tieman M. Establishing The Principles In Halal Logistics. J Emerg Econ 
Islam Res [Internet]. 2013;Vol.1:1-13. Available from: http://www.jeeir.com/index.php/jeeir/article/view/32

[7] Ali MH, Tan KH, Makhbul ZaM. Mitigating halal food integrity risk through supply chain integration. Asia Pacific Ind Eng Manag Syst. 2013;44(0):0-9.

[8] Martono RV. Logistik Halal : Peluang yang Terlepas [Internet]. 2017. Available from: https://ppm-manajemen.ac.id/id_ID/blog/artikelmanajemen-18/post/logistik-halal-peluang-yang-terlepas-1499

[9] Fazira I, Harras D, Aviastuti I, Didiet R, Hidayat R, Amonalisa S. Benchmarking Of Malaysia Certified Halal Warehouse to Implement Certified Halal Warehouse in Indonesia. Glob Res Sustain Transp Logist. 2018;1(no 1):139-49.

[10] Soraji AJ, Awang MD, Mohd Yusoff AN. Malaysia Halal Trust: Between Reality and Challenges. IJASOS- Int E-journal Adv Soc Sci. 2017;III(7):197-197.

[11] Talib MSA, Hamid ABA, Zulfakar MH, Chin TA. Barriers to Halal logistics operation: Views from Malaysian logistics experts. Int J Logist Syst Manag. 2015;22(2):193-209.

[12] Karia N. Halal logistics: practices, integration and performance of logistics service providers. J Islam Mark. 2019;

[13] Rajuldevi MK, Veeramachaneni R, Kare S. Warehousing in theory and practice: A case study at ÖoB, Clas Ohlson, Stadium, Åhlens Mahesh. 2009;(5):1-88.

[14] Zulfakar MH, Jie F, Chan C. 15 . Technology , Innovation and Supply Chain Management Interactive Session Critical success factors for a successful implementation of halal red meat supply chain in Australia: meat processor' s perspective 15. Technology, Innovation and Supply Chai. 2013;(December):1-15.

[15] Manaf Bohari A, Wei Hin C, Fuad N. An analysis on the competitiveness of halal food industry in Malaysia: an approach of SWOT and ICT strategy. Malaysia J Soc Sp. 2013;9(1):1-11.

[16] David FR. Strategic Management CONCEPTS AND CASES. THIRTEENTH. Florence, South Carolina: Pearson Education, Inc.; 2009.

[17] Development THE, Indigenous OF, Life E, As M, In AS, Achievement THE, et al. Analisis SWOT. 2016;(January).

[18] Ab Talib MS, Hamid ABA. Halal logistics in Malaysia: A SWOT analysis. J Islam Mark. 2014;5(3):322-43.

[19] Abdul Rahman NA, Mohammad MF, Abdul Rahim S, Mohd Noh H. Implementing air cargo halal warehouse: insight from Malaysia. J Islam 
Mark. 2018;9(3):462-83.

[20] Ab Talib MS, Abdul Hamid AB, Chin TA. Can halal certification influence logistics performance? J Islam Mark. 2016;7(4):461-75.

[21] Wazirah N, Shah R, Muhammad A, Mohamad S, Jaafar HS, Alam S. Halal Logistics Success Factors by Conventional Transportation Providers : A Review. J Appl Environ Biol Sci. 2016;6(9S):53-8.

[22] Zailani S, Iranmanesh M, Aziz AA, Kanapathy K. Halal logistics opportunities and challenges. J Islam Mark. 2017;8(1):127-39.

[23] Mason-Jones D.R. R and T. Article information: Revealing factors hindering halal certification in east kalimantan Indonesia. Int J Logist Manag. 1999;

[24] Alamanda DT, Anggadwita G, Raynaldi M, Novani S, Kijima K. Designing Strategies using IFE, EFE, IE, and QSPM analysis: Digital Village Case. Asian J Technol Manag. 2019;12(1):48-57. 